\title{
Diverse Novel Bacterial Endosymbionts and their Plant Growth Promoting Traits in association with Banana Plant
}

\author{
Harihar Vaidya ${ }^{1}$, Chintan Kapadia ${ }^{2 *}$, Bhavini Borse ${ }^{3}$, Trupti K. Vyas ${ }^{4}$ and Nafisa Patel ${ }^{3}$ \\ ${ }^{I}$ Naranlala ${ }^{1}$ Soil and Water Management Research Unit, ${ }^{2}$ Aspee College of Horticulture and \\ Forestry, Navsari Agriculture University, Navsari - 396450, India \\ ${ }^{3}$ Naranlala College of Professional \& Applied Science, \\ Bhagvati Sankul, Navsari - 396450, India \\ ${ }^{4}$ Food Quality Testing Laboratory, Navsari Agriculture University, Navsari-396450, India \\ *Corresponding author
}

Keywords

Antagonist activity,

Endophytes,

Organic acid,

PGPR, Phosphate

solubilisation

Article Info

Accepted:

17 January 2021

Available Online:

10 February 2021
Endophytes are endosymbiotic groups of microbes colonized in plants. These endophytes are of major interest due to multifaceted plant growth promotion (PGP) activities like production of various metabolites, their defense response towards plant pathogens and also help to combat the stress in plants. South Gujarat region is declared as an export fruit zone for mango, banana and sapota. Hence, present study aims to isolate the endophytes from the pseudostem and suckers of banana grown in South Gujarat region. Total 21 different bacteria were isolated, purified and identified by $16 \mathrm{~S}$ rRNA. Majority of the genera belongs to Bacillus followed by Klebsiella. All these isolates were evaluated for their various PGP activities like P solubilization, Indole Acetic Acid (IAA) production, organic acid production, biofilm formation and their antagonistic activity against some plant pathogenic fungi. Isolates were examined for their ability to produce various organic acids. They showed promising results in various PGP activities. Organic acid production profile was also monitored using HPLC for various organic acid secrets by isolated organisms. They were also tested for their antagonistic activity against Macrophomina phaseolina, Alternaria spp. and Sclerotinum spp. of plant pathogen and showed promising results in inhibition of these pathogens. Among all the tested isolates isolates BN2 and BN5 belongs to Klebsiella and BN9 \& BN15 belongs to Bacillus sp. showed more promising results and can be used as application of biofertilizer for banana plant. 


\section{Introduction}

Plants are associated with a diverse community of microorganisms. Rhizospheric microbes play a key role in plant growth and also in suppression of plant pathogens by various mechanisms. All these mechanisms are influenced by root exudates and they proliferates microbial communities. Microbes are also responsible for root architecture of plants and hence provide high nutrition to plants. Among this plant growth promoting rhizobacteria (PGPR), some also reside inside the plant as endophytes and form symbiotic association with plants. Endophytes reside in plants and provide some nutrients to plants and they get shelter in host plants. Their interactions are unique in each ecosystem and are less explored. These endophytes are a great source of various natural metabolites which yet not fully explored for their beneficial effect on plants (Jasim et al., 2014). As they reside inside the plants, they are more important to ameliorate the plant metabolism and plant health. Moreover, there is microbial succession of genera based on tissue type, age of plant, season of sampling.

Banana (Musa. sp) is an economically important fruit crop that is cultivated in many tropical and subtropical countries. India is a leading producer of Banana accounting for $27.43 \%$ of total banana production in the world. The important banana growing states are Tamil Nadu, Maharashtra, Gujarat, Andhra Pradesh, Karnataka, Bihar and Madhya Pradesh which together accounted for about 87.01 per cent of total banana production in the country. Among different states in the country, Gujarat has accounted for 13.44 per cent of total banana production and it ranks third in production. South Gujarat region of Gujarat State is known as export zone for mango, banana and sapota. Banana production and productivity in India are challenged by various biotic and abiotic stresses. One approach involves the use of beneficial plantassociated microorganisms such as endophytes which can offer an environmentally safe method to increase productivity and alleviate different plant stresses in addition to reducing chemical inputs. The use of such plant growth promoting endophytes as bioinoculants could reduce the use of chemical fertilizers, environmental pollution and at the same time increase the yield and productivity of medicinal and other agricultural plants (de Souza et al., 2015). Hence, present study aims to explore endophytes from banana pseudostem and its PGP traits for plant growth.

\section{Materials and Methods}

\section{Sample collection}

Different species of banana plant suckers and pseudostems were collected from Navsari Agriculture University farm at Navsari, Gujarat. Around ten species of banana suckers and its pseudostem were taken in the glass bottles and were transferred to the laboratory in cool boxes for the microbial isolation.

\section{Isolation of endophytes from banana suckers}

The banana suckers and pseudostem were surface sterilized to remove other surface bacterial load. First, the outer layer of tissues was removed with a sterile knife followed by a surface sterilized with $0.1 \%$ mercuric chloride for 10-15 min. Subsequently, it was washed thrice with sterile distilled water. $4 \mathrm{~cm}$ sterile sucker/pseudostem was added in sterile distilled water and crushed for endophytic bacteria. Sample was serially diluted and streaked on sterile Nutrient agar plates followed by incubation at room temperature for 24 to $48 \mathrm{hrs}$. Isolated colonies with different morphology were purified and stored on nutrient agar slant at $4{ }^{\circ} \mathrm{C}$ until use. 


\section{Identification of isolates}

Isolated bacteria were identified by morphological, biochemical and molecular characterization. Colony morphology on an agar plate and cell morphology was recorded by Gram's reaction. Biochemical tests were performed as per Bergey's Manual of Systematic Bacteriology.

For molecular identification, genomic DNA was extracted using the CTAB (CetylTrimethyl Ammonium Bromide) method as described by Doyle and Doyle (1987). DNA was amplified with universal primer 27f and 1592r (Vyas and Murthy 2015). PCR product was purified and sequenced using $\mathrm{ABI}$ 3130xl genetic analyzer (Applied Biosystems, CA).

Sequence was searched for homology using the BLAST tool on the National Centre for Biotechnology Information (NCBI). Sequence was submitted to GenBank for accession number.

\section{PGPR traits of endophytes}

Isolated endophytic bacteria were screened for their following multiple PGP traits.

\section{Indole acetic acid production}

Isolates were screened for IAA production using methods described by Bric and coworkers (1991). Briefly $1 \%$ of $18 \mathrm{hrs}$ grown culture of isolated bacteria was inoculated in $50 \mathrm{ml}$ of nutrient broth and nutrient broth supplemented with tryptophan $(1 \mathrm{mg} / \mathrm{ml})$ as described by Vadnerker and co-worker (2018). After 3 days incubation, quantification was done using Salkowsky's reagent and optical density was measured at $535 \mathrm{~nm}$. The concentration of IAA was extrapolated from the standard curve of IAA prepared using 100 $\mu \mathrm{g} / \mathrm{ml}$ of standard IAA.

\section{Phosphate solubilization}

Phosphate solubilization was quantified using the method described by Subba Rao (1988). Isolates were grown in Pikovskaya's Broth and incubated for 7 days. The concentration of the soluble phosphate was estimated by stannous chloride method at $430 \mathrm{~nm}$. Soluble P was extrapolated from the standard curve $(0-20$ $\mu \mathrm{g} / \mathrm{ml})$.

\section{Organic acid profiling}

Organic acid produced by bacteria lowers the $\mathrm{pH}$ and thus solubilize the $\mathrm{P}$ and other elements and thus make it available for plants. Various organic acids produced by bacteria were measured by HPLC. For organic acid profiling, cells were grown in Pikovskaya's Broth and after incubation cell free supernatant was collected. Supernatant was further passed through $0.2 \mu \mathrm{m}$ pore size Millipore filter to remove any cell present in supernatant. Organic acid was estimated using C18 reversed phase HPLC column (250 mm x $4.6 \mathrm{~mm}$ with $5 \mu \mathrm{m}$ particle sizes) using $0.008 \%$ sulphuric acid as mobile phase at flow rate of $1.0 \mathrm{ml} / \mathrm{min}$. Organic acid present in the sample was detected $190 \mathrm{~nm}$ using PDA detector (Scherer 2012). Fumaric acid, Citric acid, Propianoic acid, Acetic acid, Lactic acid, Malic acid, Pyruvic acid, Oxalic acid, Glutamic acid was run standard.

\section{Ammonia production}

Ammonia production was quantified by growing cells in peptone water for 3 days at room temperature. Supernatant was collected by centrifugation at $8000 \mathrm{rpm}$ for $10 \mathrm{~min}$. 0.5 $\mathrm{ml}$ of Nessler's reagent was added in $3 \mathrm{ml}$ supernatant (Cappucino and Sherman 1992). If ammonia is produced by isolates, they develop brown to yellow color which is quantified at $450 \mathrm{~nm}$. The concentration of ammonia was extrapolated from the standard curve of ammonium. 


\section{Hydrogen cyanide (HCN) production}

To examine $\mathrm{HCN}$ production, isolated bacteria were individually streaked on Nutrient Agar supplement with Glycine. A whatman filter paper number 1 soaked in $2 \% \mathrm{w} / \mathrm{v}$ sodium carbonate in $0.5 \%$ picric acid solution was placed inside the lid of a petri plate. Petri plates were sealed with parafilm and incubated at room temperature for 2 days. A change in the filter paper color from yellow to brown was considered positive for $\mathrm{HCN}$ production (Lorck 1948).

\section{Biofilm formation}

Biofilm formation was observed by growing cells in LB broth in the test tube for 24 hrs. After $24 \mathrm{hrs}$, media broth was removed and biofilm formation on the test tube wall was visualized by staining using methylene blue. Isolates that were able to form biofilm showed purple color ring or purple color walls. Potential isolates were examined for quantitative EPS production by phenolsulfuric assay (Dubois et al., 1951).

\section{EC tolerance}

All the potential isolates were tested for their ability to tolerate EC. For EC tolerance, LB medium was adjusted to various EC such as 2, 4, 6 EC. Each flask was inoculated with $0.1 \mathrm{ml}$ of $24 \mathrm{~h}$ old bacterial culture broth and incubated at room temperature. Growth was monitored in terms of increased OD at $660 \mathrm{~nm}$ at $24 \mathrm{hrs}$ interval upto $72 \mathrm{hrs}$.

\section{Antagonistic activity}

The endophytic isolates were tested for their antagonistic response against plant pathogens Macrophomina phaseolina, Alternaria and Sclerotoium by dual culture method (Fokkema 1978). All the plates were incubated at room temperature for 7 days and observed for determination of antagonistic activity. Potential isolates were further tested for quantitative evaluation for their antagonistic potential. The quantitative evaluation of antagonism by test strain was carried out by the method described by Trivedi and coworker (2008) with some modification. The test strains were allowed to grow for 24 hours in the LB broth. Simultaneously the phytopathogens (Macrophomina phaseolina, Alternaria sp. and Sclerotoium sp.) were allowed to grow for $48 \mathrm{hrs}$ in PDA broth. 50 $\mu \mathrm{l}$ of overnight grown bacterial cultures were inoculated into the PDA broth containing respective pathogenic fungi. The broth having only fungi was kept as control for determination of inhibition percentages. After incubation of $48 \mathrm{hrs}$, the culture was passed through pre-weighed filter paper and filter paper was dried. Biomass was measured as difference with control flask. The dry weight of fungi + bacteria (W2) and fungi alone (W1) were recorded and $\%$ reduction in weight was calculated using the formula: (W1-W2/W1) $\times 100$.

\section{Results and Discussion}

\section{Isolation of endophytes from banana suckers}

From the various samples of banana sucker and pseudostem, total 21 (designated BN1 to BN21) different bacteria were isolated. All these bacteria were selected based on different colony morphology and were isolated and purified. These isolates were stored on nutrient agar slant until use.

\section{Identification of isolates}

All the bacteria were identified for their morphological, biochemical and molecular characterization. Colony characteristics of the 21 bacterial endophytes from suckers and pseudostem of banana plant were noted. They 
were round or irregular, smooth, medium, moist or dry, translucent to opaque, flat, raised to convex. Biochemical characteristics like methyl red(MR), Vogesproskauer(VP), oxidase, catalase, indole production, urea hydrolysis, gelatin hydrolysis, citrate production, nitrate reduction, and fermentation of sugar like ribose, lactose, galactose, sucrose, maltose etc were recorded (data not shown here). All these isolates were identified using 16S rRNA and sequence was submitted to GenBank for accession number. Among divers endophytes isolated, the highest number of isolates belongs to genera Bacillus, followed by Klebsiella sp. (Fig. 1).

\section{PGPR traits of endophytes}

\section{Indole acetic acid production}

IAA is important for plant growth promotion activity. All the isolates were evaluated for their ability for production of IAA. All isolates were able to produce IAA as they form pink color on reaction with salkowski reagent. However among all these isolates, BN1 produced highest IAA (259 ppm) whereas, BN12 produced least (17 ppm) (Fig. 2a).

\section{Phosphate solubilization}

All the isolates were tested for their ability to solubilize phosphate and revealed that all were able to solubilize Tri calcium phosphate. Among all the isolates BN6 (275 ppm) showed highest $\mathrm{P}$ solubilization followed by BN13 (244 ppm) (Fig. 2b). Least was reported in BN20 (15ppm).

\section{Organic acid production}

One of the important traits of PGPRs is organic acid production. Organic acid production lowers the soil $\mathrm{pH}$ and thus increases availability of $\mathrm{P}$ to plant. Hence, all the isolates were tested for their ability to produce nine different organic acid viz., acetic, citric, formic, glutamic, lactic, malonic, oxalic, propionic and pyruvic acid. Isolates grown in pikovskaya broth supplemented with tri-calcium were observed using HPLC. Data revealed that all the isolates produced one or more organic acids in the medium. Among all the acids evaluated, all the isolates except four were able to produce formic acid. Another major acid production by majority isolates was citric acid followed by oxalic acid and propionic acid. Thus production of difference acid by isolates fell in the category from higher to lower as formic acid > citric acid > oxalic acid and propionic acid $>$ glutamic acid $>$ lactic acid > pyruvic acid > malonic acid > acetic acid. Thus only three isolates were able to produce acetic acid (Table 1).

\section{Ammonia production}

All the isolates showed positive for ammonia production. Higher ammonia production was reported in BN17 (1.60 ppm) followed by BN8 (1.21 ppm) (Fig. 3a). Least was reported in BN7 (0.36 ppm). After three days of incubation on estimating ammonia, maximum concentration of ammonia was produced1.065 $\pm 0.135 \mathrm{ppm}$ by $\mathrm{BN} 8$ and $\mathrm{BN}$ 17 and isolates, minimum amount ammonia production $0.43 \pm 0.04$ ppm produced by BN 4 .

\section{Hydrogen cyanide (HCN) production}

HCN production was examined for all the isolated bacteria. All these isolates changed the yellow color filter paper to brown color and showed positive for $\mathrm{HCN}$ production.

\section{Biofilm formation}

All the isolates were tested for their ability to form biofilm. When they have stained with crystal violet, BN9 showed the positive for biofilm. BN9 which showed positive for biofilm was further evaluated for the amount 
of exopolysaccharide produced by isolate. Phenol sulfuric assay revealed that it produced $27 \mu \mathrm{g} / \mathrm{ml}$ of EPS. Thus, BN9 was able to secrete polysaccharide which probably plays a role in their biofilm formation.

\section{EC tolerance}

EC, $\mathrm{pH}$ and salt tolerance was also examined for all the isolated PGPRs. All the isolates were able to grow in broth having 2, 4 and 6 EC. Increased in growth was monitored after $24 \mathrm{hrs}$ at $24 \mathrm{hrs}$ interval up to $72 \mathrm{hrs}$ at 660 $\mathrm{nm}$. Highest growth was achieved after $72 \mathrm{hrs}$ of incubation in 2, 4 and $6 \mathrm{EC}$ (Fig. 3b).

\section{Antagonistic activity}

All the isolates were examined for their antagonistic activity against plant pathogens Macrophomina phaseolina, Alternaria and Sclerotoium by dual culture method. Macrophomina phaseolina pathogen was inhibited by BN2, BN3, BN15 and BN16 PGPRs, whereas, Sclerotoium was inhibited by BN4 and BN5.

Alternaria was inhibited by BN9, BN10, BN15 and BN16. These isolates which showed inhibition of pathogenic fungi were further tested for their quantitative ability to inhibit plant pathogens.

Rests of the isolates were not able to show antagonistic activity. In quantitative antagonistic assay, highest inhibition of Macrophomina was observed by BN2 (91\%) followed by BN3 (Fig. 4). Sclerotoium was inhibited $90 \%$ by BN4 and BN5, whereas, Alternaria was highest inhibited by BN9 (98 $\%$ ) followed by BN15 (Fig. 4). Thus, some endophytes were able to suppress growth of tested plant pathogens. Banana is important plant and hence, interaction of microbes with banana plants plays a crucial role in either beneficial or deleterious effects on plants. In the present study, diverse endophytic bacteria associated with banana pseudostem and suckers were isolated for their various PGP traits. Total 21 isolates based on their diverse colony morphology were selected and purified for further studies.

As PGPR, isolated endophytes can increase the growth of plants directly, indirectly or synergistically (Bhattacharyya and Jha 2012).

Some direct mechanisms of PGPRs are $\mathrm{P}$ solubilization, IAA production, $\mathrm{N}$ fixation, etc. (Mullen MD 2005; Glick BR 1995), whereas, some indirect PGP activities are production of antimicrobial compounds, $\mathrm{HCN}$ production, chitinase production, siderophore production etc.

Total 21 PGPR isolates belonged to 10 different genera. Among them, the major belonged to Bacillus (7 isolates), followed by Klebsiella (4 isolates). Their morphological examination revealed that out of 21 isolates, 8 were Gram positive whereas, rests 13 were Gram negative.

Thus, Gram negative bacteria were dominating in association with banana plants. Some unique associations were also observed like the presence of Kosakonia oryzae and Pantoea which are majority reported in association with paddy. Klebsiella (4 isolates) and Rhizobium (2 isolates) were also present indicating their ability to fix nitrogen. Su and co-worker (2017) have also reported 11 different genera from banana endophytes and evaluated their antagonistic effects against nematodes. Zakaria and Aziz (2018) have worked on fungal endophytes of banana leaves.

They have reported isolates belonged to 10 different genera and comprised 17 different species. Karthik and co-worker (2017) have also reported 8 genera and 10 species. 
Table.1 Organic acid $(\mu \mathrm{g} / \mathrm{ml})$ production by various isolated endophytic bacteria from banana plant

\begin{tabular}{|c|c|c|c|c|c|c|c|c|c|}
\hline Isolates & Acetic acid & Citric acid & $\begin{array}{c}\text { Formic } \\
\text { acid }\end{array}$ & $\begin{array}{c}\text { Glutamic } \\
\text { acid }\end{array}$ & Lactic acid & $\begin{array}{c}\text { Malonic } \\
\text { acid }\end{array}$ & Oxalic acid & $\begin{array}{c}\text { Propionic } \\
\text { acid }\end{array}$ & $\begin{array}{c}\text { Pyruvic } \\
\text { acid }\end{array}$ \\
\hline BN1 & - & 12.6 & 204 & 57.11 & - & - & - & 32.4 & 8.76 \\
\hline BN2 & - & - & 0.72 & 0.261 & 23.96 & - & 11.9 & 0.37 & - \\
\hline BN 3 & 1.66 & 64.4 & 98.6 & - & 31.84 & 0.052 & - & 1.66 & - \\
\hline BN 4 & - & 1.83 & 111 & - & - & - & - & - & 51.1 \\
\hline BN 5 & - & 12.6 & 134 & - & 15.88 & - & - & - & - \\
\hline BN 6 & 5.64 & - & 92.4 & - & - & - & 5.64 & - & - \\
\hline BN 7 & - & 32.3 & 111 & - & - & - & - & - & - \\
\hline BN 8 & - & 9.22 & - & - & 14.06 & - & 1.49 & 1183 & - \\
\hline BN 9 & - & - & - & - & - & - & 1.30 & 2.33 & - \\
\hline BN 10 & - & - & 111 & - & 2.602 & - & 1.69 & 176 & - \\
\hline BN 11 & - & - & 101 & - & - & 6.29 & - & - & 38.0 \\
\hline BN 12 & - & - & 40.9 & 0.059 & - & 0.5799 & 0.98 & 0.10 & 66.6 \\
\hline BN 13 & - & 1.05 & - & 0.077 & 0.3949 & - & - & - & 110 \\
\hline BN 14 & - & 0.02 & 100. & - & - & - & - & - & - \\
\hline BN 15 & - & 56.2 & 83.2 & - & - & - & 2.46 & - & - \\
\hline BN 16 & - & 33.2 & 91.1 & - & - & - & 2.11 & - & - \\
\hline BN 17 & - & 165 & 91.9 & - & - & - & - & - & - \\
\hline BN 18 & 11.2 & - & 91.1 & - & - & - & - & 5.29 & - \\
\hline BN 19 & - & 2.29 & 125 & 39.56 & - & 2.3692 & - & 2.39 & - \\
\hline BN 20 & - & - & 92.3 & 0.699 & - & - & - & - & - \\
\hline BN 21 & - & - & - & 0.270 & - & - & 6.73 & - & - \\
\hline
\end{tabular}


Fig.1 Phylogenetic tree of the endophytes isolated from banana plants

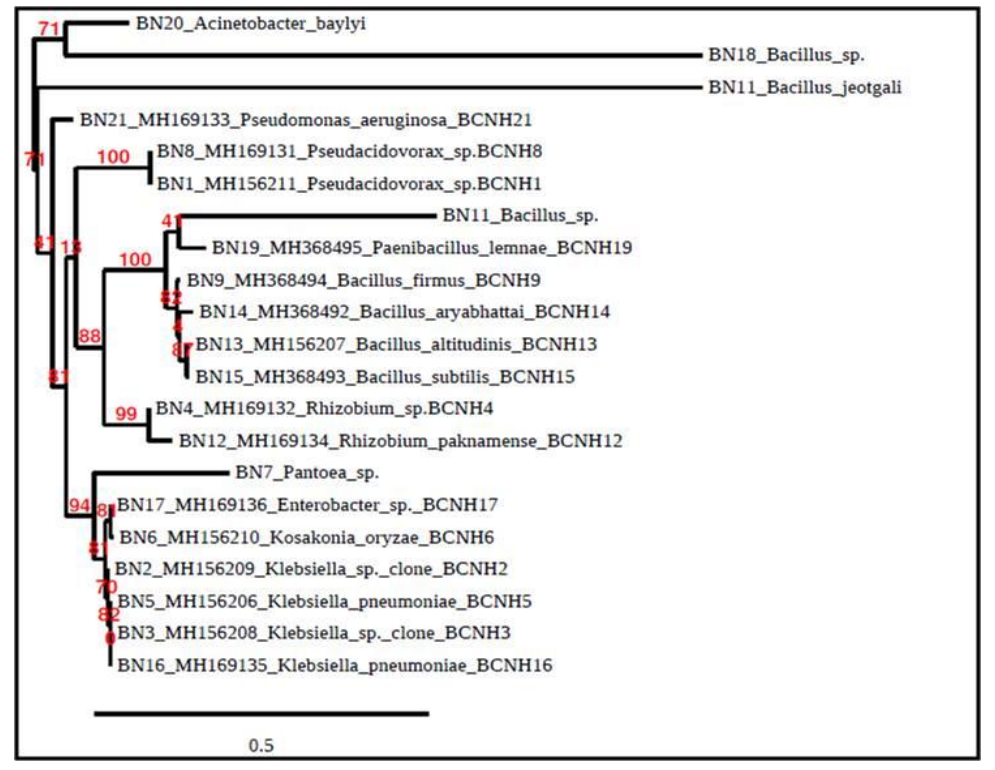

Fig.2 Production of IAA (a) and P solubilization (b) by banana endophytes

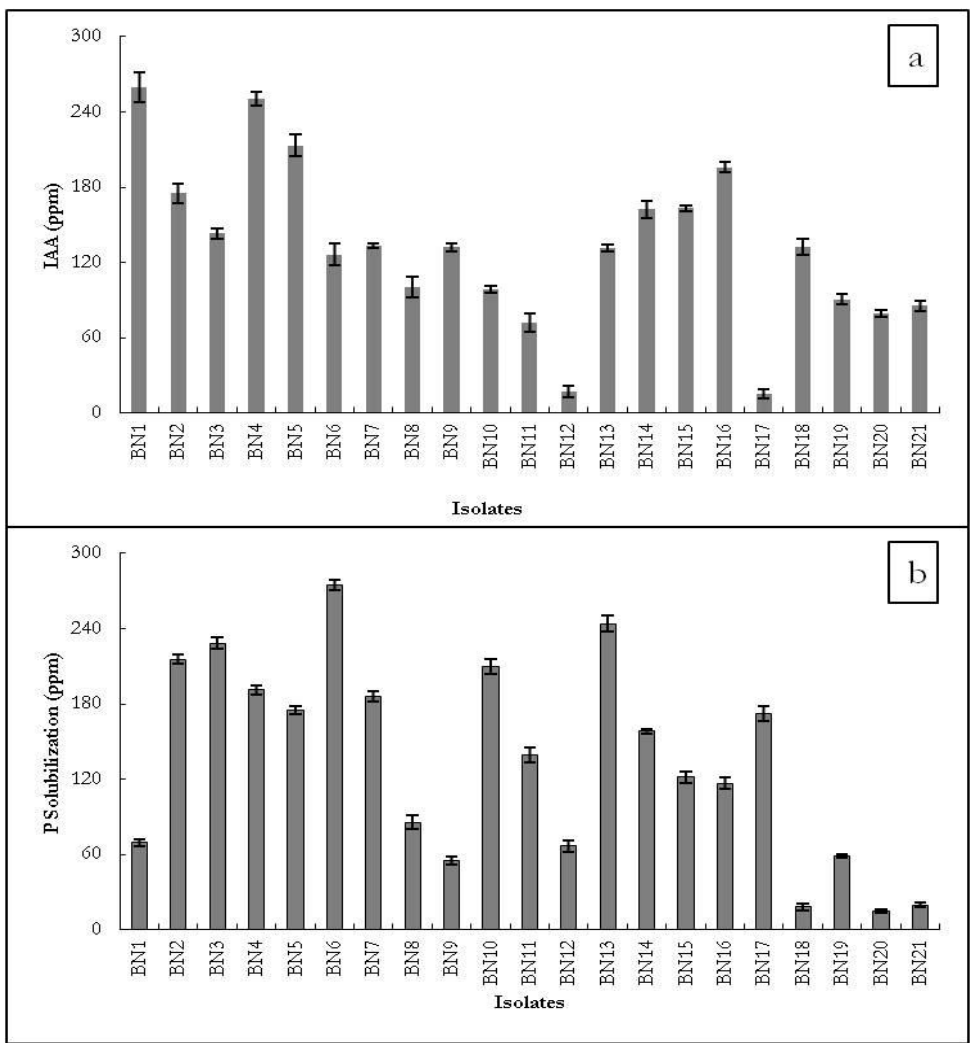


Fig.3 Ammonia production (a) and EC tolerance (b) by banana endophytes

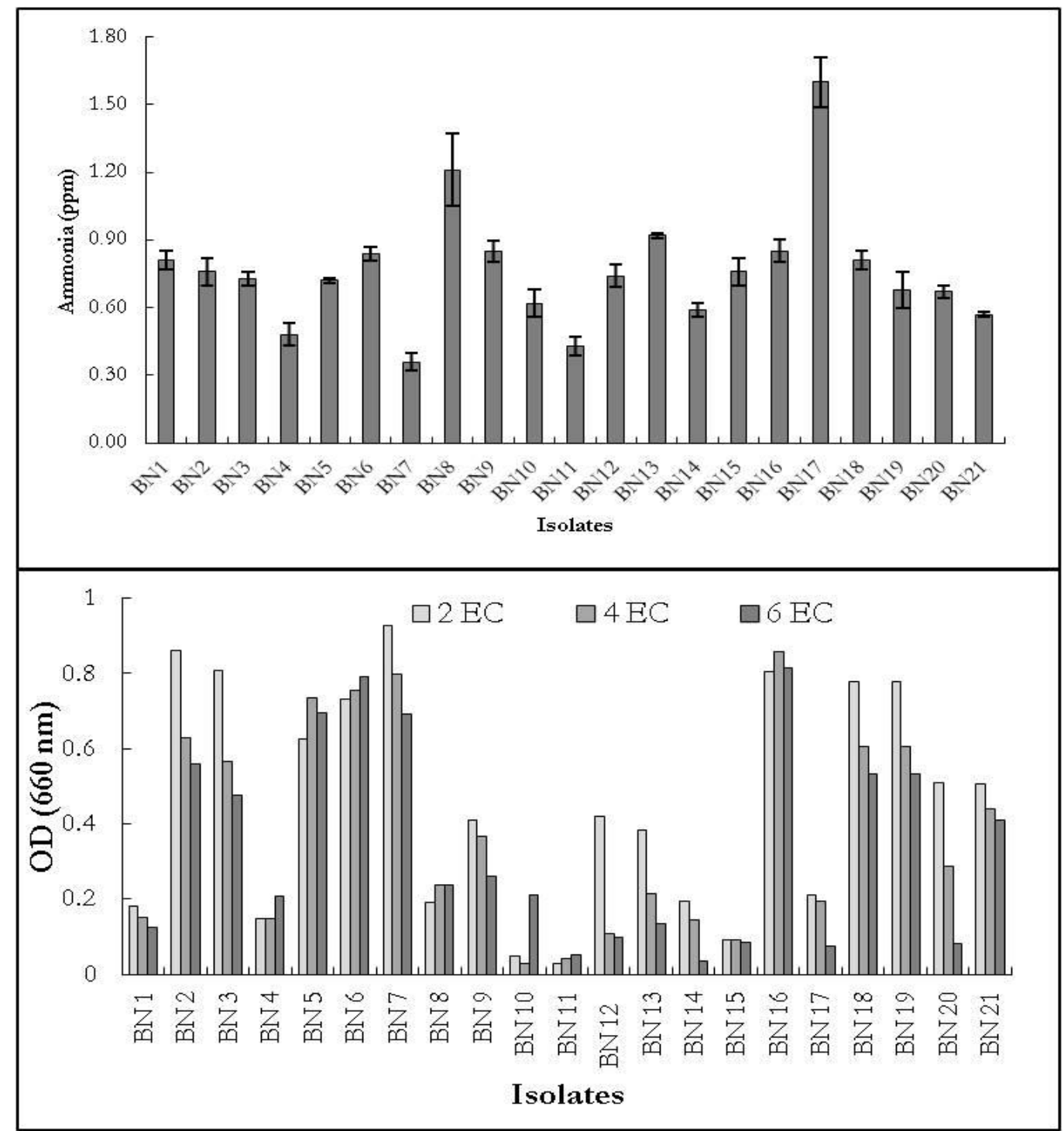


Fig.4 Antagonistic activity of isolates against plant pathogens

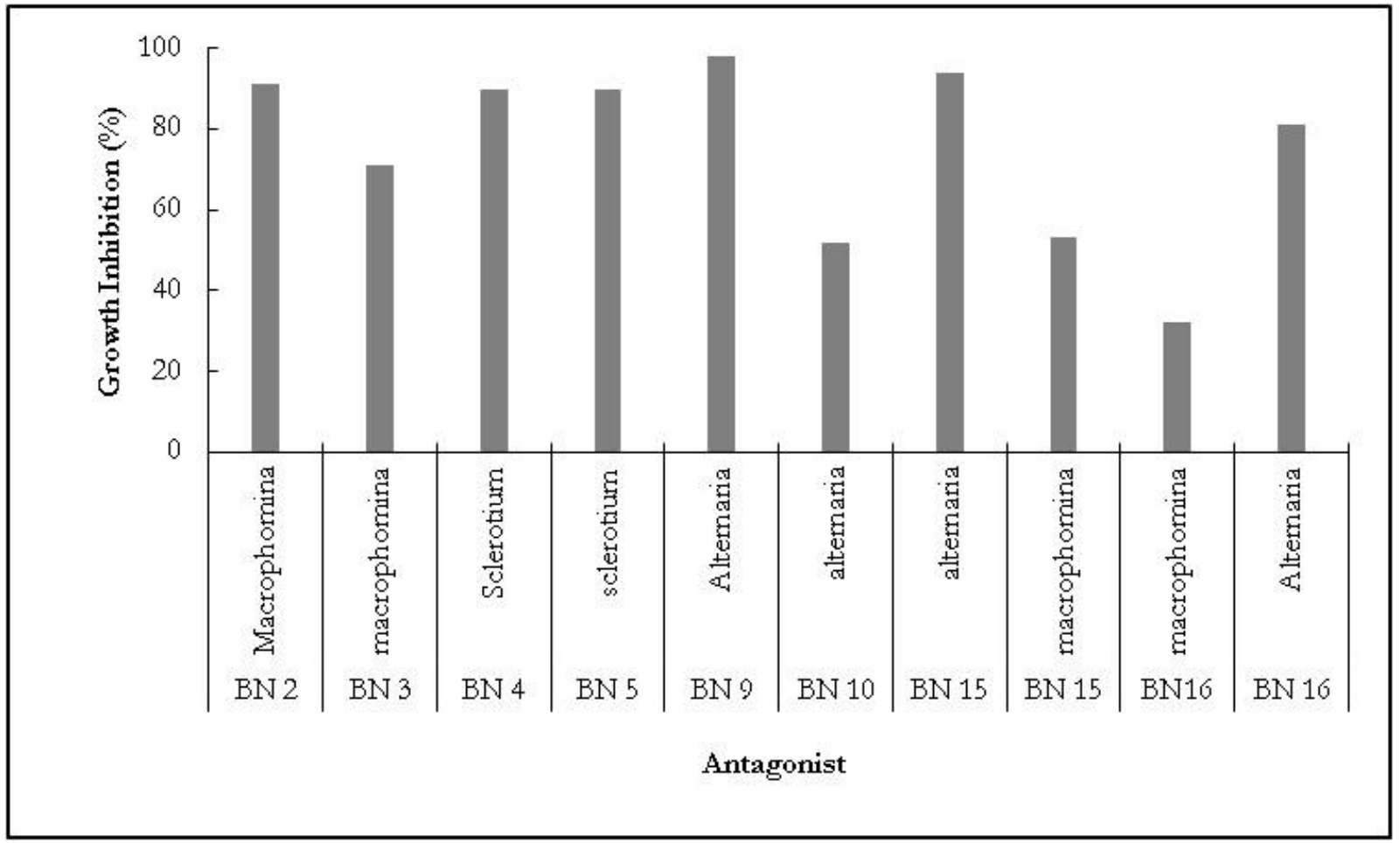

All these data are in accordance with present findings where they have reported Bacillus, Klebsiella, Pseudomonas and Rhizobium are common genera (Zakaria and Aziz 2018; Su et al., 2017). Vyas and co-worker (2017) have also reported that application of organic manure has more growth promotion in banana plant compared to control or inorganic manure application.

Another PGP trait of bacteria is production of phytohormone IAA. IAA is an important plant hormone in play a role in differentiation of cell, cell division, apical growth, development of root, initiation of lateral root formation etc. Apart from this, IAA is also required in some physiological processes like photosynthesis, pigment synthesis, formation of various metabolites and providing resistance in stress conditions (Ryu and Patten 2008). As IAA is responsible for increased root length and initiation of lateral root formation, consequently uptake of nutrients is also increased and thus overall plant growth (Vessey, 2003). In the present report all the isolates showed positive for IAA production. BN1 was reported as a potential IAA $(281 \mu \mathrm{g} /$ $\mathrm{ml}$ ) producer.

In soil, the majority of the phosphate is either immobilized or unavailable for plants. However, PGPR produces organic acid and solubilizes $\mathrm{P}$ and makes it in available form. However, total organic acid production by the various microbes is very important to determine the solubilization of phosphate rather than considering individual acid (Oburger et al., 2009; Chen et al., 2006; Song et al., 2008). There is always ambiguity regarding various organic acids produced by various isolates due to complex growth requirements and physiological status (Pérez et al., 2007). Our results are in accordance with de Abreu and coworkers (2017). They have reported that various bacterial isolates belongs to Bacillus and Enterobacter were 
able to solubilize P. However, majority of the reports showed that gluconic acid, 2ketogluconic acid and oxalic acids are the major acid produced by PGPR during $\mathrm{P}$ solubilization (Behera et al., 2017; de Abreu et al., 2017). Thus present data are in contrast to the mentioned reports.

In present study isolates were evaluated for their ability to produce ammonia and $\mathrm{HCN}$. These both activities were positive for all the isolated bacteria. The current study showed that isolated twenty one bacteria Klebsiella spp. had remarkable antagonism against test pathogens Alternaria sp., Macrophomina sp. and Sclerotium sp. Among them, Klebsiella spp. was found to be more antagonistic against most of the test pathogens followed by the Bacillus, which predomibately inhibit growth of Alternaria sp. Similarly, Rhizobium exhibited antagonistic activity against Sclerotium sp. Antagonistic activities of endophytic bacteria facilitate the plants to survive in the biotic stress. Similarly, Bacillus, Klebsiella sp and Pseudomonas sp showed anti fungal effect against test pathogen Sclerotum rolfsi, Macrophomina phaseolina, Alternaria sp, Fusarium solani and Fusarium oxysporium (Karthikeyan et al., 2006; Hameeda et al., 2006; Senthilkumar et al., 2009; Das et al., 2015). There may be inhibitory volatile and diffusible metabolites produced by the isolated microbes which sometimes inhibit the toxin production of the fungi (Shifa et al., 2015). The isolates may produce of bacteriocins, lytic enzymes as well as siderophore. Among the reported various fungal and bacterial isolates so far, $\mathrm{BN} 2, \mathrm{BN} 9$, BN4,BN5 and BN 15 could be the most potential isolates to inhibit growth of test fungi. By the use of such biocontrol agents with PGPR activities could substantially reduce the cost of chemicals. Shifa and coworker (2015) tested efficacy of biocontrol strain Bacillus subtilis strain G-1 and recorded an inhibition of $28 \%$ in mycelial growth of $S$. rolfsii. Endophyte of root nodules of Vigna mungo L. identified as Klebsiella pneumonia possessed antagonistic effect and inhibited $73.3 \%$ and $50.8 \%$ growth of M. phaseolina and A. alternate respectively. Their study is consistent with the results of the current work. There are several reports supports our claim of antagonism of Bacillus Sp. against Sclerotium and Macrophomina phaseolina by Bacillus subtilis (Liu et al., 2008).

Plant growth promoting bacterial endosymbiont are gaining interest due to their multiple beneficial effects on plant growth and as biocontrol agents. Present study reported novel diversity of banana endophytes and their plant growth promoting activities. All possess different PGP activity however, together synergistically they provide the majority of the macro and micro nutrients requirement to the plant. Along with these, they are also able to suppress some plant pathogens like Macrophomina, sclerotium and alternaria. Among all the isolates Bacillus and Klebsiella possess majority of all PGP traits and antagonistic activity. Hence, together both these isolates can be used as biofertilizer and biocontrol agent for banana plant. Present study reports both, diversity of endophytes and their PGP traits which are not reported yet.

\section{References}

Behera BC, Yadav H, Singh SK, et al., (2017) Phosphate solubilization and acid phosphatase activity of Serratia sp. isolated from mangrove soil of Mahanadi river delta, Odisha, India. J Genet Eng Biotechnol 15:169-178. doi: 10.1016/j.jgeb.2017.01.003

Bhattacharyya PN, Jha DK (2012) Plant growthpromoting rhizobacteria (PGPR): Emergence in agriculture. World $\mathrm{J}$ Microbiol Biotechnol., 28:1327-1350. doi: 10.1007/s11274-011-0979-9

Bric JM, Bostock RM, Silverstone SE (1991) 
Rapid in situ assay for indoleacetic acid production by bacteria immobilized on a nitrocellulose membrane. Appl Environ Microbiol 57:535-538. doi: 10.1128/aem.57.2.535-538.1991

Cappucino JC, Sherman N. Microbiology: a laboratory manual, 3rd ed. Benjamin/Cumming Pub. Co, New York, 1992.

Chen YP, Rekha PD, Arun AB, et al., (2006) Phosphate solubilizing bacteria from subtropical soil and their tricalcium phosphate solubilizing abilities. Appl Soil Ecol 34:33-41. doi: 10.1016/j.apsoil.2005.12.002

Das MP, Vennila Devi P, Yasmine Y (2015) A study on antagonistic potential of bacteria against phytopathogenic fungi. Int J Pharm Sci Rev Res 34:191-193

de Abreu CS, Figueiredo JEF, Oliveira CA, et al., (2017) Maize endophytic bacteria as mineral phosphate solubilizers. Genet Mol Res 16. doi: 10.4238/gmr16019294

de Souza R, Ambrosini A, Passaglia LMP (2015) Plant growth-promoting bacteria as inoculants in agricultural soils. Genet Mol Biol 38:401-419. doi: 10.1590/S1415475738420150053

Doyle, JJ, Doyle J (1990) Doyle\&Doyle_Focus_1990_CTAB.pdf.

Focus (Madison). 12:13-15

Dubois M, Gilles K, Hamilton JK, et al., (1951) A colorimetric method for the determination of sugars. Nature 168:167. doi: $10.1038 / 168167 \mathrm{a} 0$

Fokkema NJ (1978) Fungal antagonisms in the phyllosphere, Annals Appl Biol 89(1): 115-119.

Foundation M (1929) Calorimetric Determination of Sulfates. 713-721

Glick BR (1995) The enhancement of plant growth by free-living bacteria. Can J Microbiol 41:109-117. doi: 10.1139/m95015

Hameeda B, Harini G, Rupela OP, et al., (2008) Growth promotion of maize by phosphatesolubilizing bacteria isolated from composts and macrofauna. Microbiol Res 163:234-242.

doi: 10.1016/j.micres.2006.05.009

Jasim B, Joseph AA, John CJ, et al., (2014) Isolation and characterization of plant growth promoting endophytic bacteria from the rhizome of Zingiber officinale. 3 Biotech 4:197-204. doi: 10.1007/s13205013-0143-3

Karthik M, Pushpakanth P, Krishnamoorthy R, Senthilkumar M (2017) Endophytic bacteria associated with banana cultivars and their inoculation effect on plant growth. J Hortic Sci Biotechnol 92:568576.

doi:

10.1080/14620316.2017.1310600

Karthikeyan V, Sankaralingam A, Nakkeeran S (2006) Biological control of groundnut stem rot caused by Sclerotium rolfsii (Sacc.). Arch Phytopathol Plant Prot 39:239-246. doi: 10.1080/03235400500094688

Liu W wei, Mu W, Zhu B yu, et al., (2008) Antagonistic Activities of Volatiles from Four Strains of Bacillus spp. and Paenibacillus spp. Against Soil-Borne Plant Pathogens. Agric Sci China 7:11041114. doi: 10.1016/S1671-2927(08)601534

Lorck H (1948) Production of Hydrocyanic Acid by Bacteria. Physiol Plant 1:142-146. doi: 10.1111/j.1399-3054.1948.tb07118.x

Mullen MD (2005) Phosphorus in soils: biological interactions. In: D. Hillel, C. Rosenzweig, D. Powlson, K. Scow, M. Singer, D. Sparks (eds).Encyclopedia of Soils in the Environment, Vol.3. Academic Press, Elsevier, Ltd, Oxford, pp: 210-215.

Oburger E, Kirk GJD, Wenzel WW, et al., (2009) Interactive effects of organic acids in the rhizosphere. Soil Biol Biochem 41:449-457.

doi: 10.1016/j.soilbio.2008.10.034

Pérez E, Sulbarán M, Ball MM, Yarzábal LA (2007) Isolation and characterization of mineral phosphate-solubilizing bacteria naturally colonizing a limonitic crust in the south-eastern Venezuelan region. Soil Biol Biochem 39:2905-2914. doi: 10.1016/j.soilbio.2007.06.017 
Ryu RJ, Patten CL (2008) Aromatic amino aciddependent expression of indole-3-pyruvate decarboxylase is regulated by tyrr in Enterobacter cloacae UW5. J Bacteriol 190:7200-7208. doi: 10.1128/JB.0080408

Scherer R, Rybka ACP, Ballus CA, et al., (2012) Validation of a HPLC method for simultaneous determination of main organic acids in fruits and juices. Food Chem 135:150-154. doi: 10.1016/j.foodchem.2012.03.111

Senthilkumar M, Swarnalakshmi K, Govindasamy V, et al., (2009) Biocontrol potential of soybean bacterial endophytes against charcoal rot fungus, Rhizoctonia bataticola. Curr Microbiol 58:288-293. doi: 10.1007/s00284-008-9329-z

Shifa H, Gopalakrishnan C, Velazhahan R (2014) Efficacy of Bacillus subtilis G-1 in suppression of stem rot caused by Sclerotium rolfsii and growth promotion of groundnut. Int $\mathrm{J}$ Agric Environ Biotechnol 8:111. doi: 10.5958/2230732x.2015.00015.7

Song OR, Lee SJ, Lee YS, et al., (2008) Solubilization of insoluble inorganic phosphate by Burkholderia cepacia DA23 isolated from cultivated soil. Brazilian J Microbiol 39:151-156. doi: 10.1590/S1517-83822008000100030

Su L, Shen Z, Ruan Y, et al., (2017) Isolation of antagonistic endophytes from banana roots against Meloidogyne javanica and their effects on soil nematode community. Front
Microbiol 8:1-11. doi: 10.3389/fmicb.2017.02070

Subbarao NS (1988) Phosphate solubilizing microorganism. In: Biofertilizer in agriculture and forestry. Regional Biofert. Dev. Centre, Hissar, India. pp. 133-142.

Trivedi P, Pandey A, Palni LMS (2008) In vitro evaluation of antagonistic properties of Pseudomonas corrugata. Microbiol Res 163:329-336. doi: 10.1016/j.micres.2006.06.007

Vadnerker PS, Vyas TK, Kapadia C, Gandhi A (2018) Multifaceted plant growth promoting potentials of Pseudomonas aeruginosa AP isolated from Dandi, Gujarat, India. 6:8528

Vessey JK (2003) Plant growth promoting rhizobacteria as biofertilizers. Plant Soil 255:571-586.

doi: 10.1023/A:1026037216893

Vyas TK, Desai P, Patel A, Patel S, Patel KG (2017) Exploring effect of various organic manure on microbial community of soil from banana organic farm. 8:156-159.

Vyas TK, Murthy SR (2015) Chlorobenzene degradation by Bacillus sp. TAS6CB: A potential candidate to remediate chlorinated hydrocarbon contaminated sites. J Basic Microbiol 55:382-388. doi: 10.1002/jobm.201200758

Zakaria L, Aziz WNW (2018) Molecular identification of endophytic fungi from banana leaves (Musa spp.). Trop Life Sci Res 29:201-211. doi: 10.21315/tlsr2018.29.2.14

\section{How to cite this article:}

Harihar Vaidya, Chintan Kapadia, Bhavini Borse, Trupti K. Vyas and Nafisa Patel. 2021. Diverse Novel Bacterial Endosymbionts and their Plant Growth Promoting Traits in association with Banana Plant. Int.J.Curr.Microbiol.App.Sci. 10(02): 2047-2059. doi: https://doi.org/10.20546/ijcmas.2021.1002.244 